\title{
PENINGKATAN HASIL BELAJAR BAHASA INDONESIA MELALUI PEMBELAJARAN KOOPERATIF TIPE QUESTION STUDENT HAVE PADA SISWA KELAS XII IPA 1 SMA NEGERI 10 BULUKUMBA
}

\author{
Muhammad Asdar ${ }^{1}$ \\ SMA Negeri 10 Bulukumba \\ Coresponding Email : muhasdarusman@gmail.com
}

\begin{abstract}
ABSTRAK
Penelitian ini bermaksud untuk mengetahui penerapan dalam pembelajaran kooperatif tipe Question Student Have dalam meningkatkan hasil belajar Bahasa Indonesia siswa Kelas XII IPA 1 SMA Negeri 10 Bulukumba. Penelitian ini merupakan penelitian tindakkan kelas (classroom action research). Penelitian ini terdiri atas serangkaian siklus, setiap siklus meliputi empat tahap yaitu : perencanaan, pelaksanaan tindakan, observasi dan refleksi. Subjek dalam penelitian ini adalah siswa kelas XII IPA 1 SMA Negeri 10 Bulukumba tahun pelajaran 2017/2018 semister genap yang berjumlah sebanyak 24 siswa, terdiri dari 5 siswa laki-laki dan 19 siswa perempuan. Adapun Instrumen yang digunakan dalam penelitian ini adalah Lembar observasi dan test. Teknik analisis data yang digunakan dalam penelitian ini menggunakan analisis data deskriptif kualitatif. Analisis data kualitatif digunakan untuk mengolah data hasil observasi guru dan siswa. Adapun teknik data deskriptif kualitatif digunakan untuk menghitung presentase nilai rata - rata. Kriteria Ketuntasan Minimal (KKM) yang diterapkan pada mata pelajaran Fisika adalah 75. Jadi nilai siswa dapat dikatakan tuntas apabila mencapai nilai KKM (Kriteria Ketuntasan Minimal). Berdasarkan analisis data dan pembahasan, maka dapat ditarik kesimpulan bahwa hasil belajar Bahasa Indonesia siswa Kelas XII IPA 1 SMA Negeri 10 Bulukumba mengalami peningkatan setelah diadakan pembelajaran kooperatif tipe Question Student Have, dengan indikasi sebagai berikut (1) Hasil belajar Bahasa Indonesia siswa Kelas XII IPA 1 SMA Negeri 10 Bulukumba setelah diberi tindakan pada Siklus I berada pada kategori sedang dengan skor rata-rata 66,70 dari skor ideal 100, (2) Hasil belajar Bahasa Indonesia siswa Kelas XII IPA 1 SMA Negeri 10 Bulukumba setelah diberi tindakan pada Siklus II berada pada kategori tinggi dengan skor rata-rata 79,12 dari skor ideal 100, (3) Terjadi peningkatan hasil belajar siswa dari kategori sedang pada Siklus I dan Siklus II pada kategori tinggi dengan skor rata-rata 66,70 menjadi 79,12 sehingga mengalami peningkatan, (4) Persentase kehadiran siswa juga mengalami peningkatan dari 97,5 persen menjadi 98,3 persen pada siklus II, dan (5) Pembelajaran kooperatif tipe Question Student Have dalam kegiatan belajar mengajar dapat memberikan motivasi kepada siswa agar lebih inovatif dan kreatif dalam membuat pertanyaan serta mengemukakan pertanyaan - pertanyaan dan tidak canggung untuk mengemukakan pendapatnya
\end{abstract}

Kata kunci: Hasil Belajar, Bahasa Indonesia, Pembelajaran Kooperatif, Question Student Have

\section{PENDAHULUAN}

Perkembangan ilmu pengetahuan dan teknologi pada saat ini berkembang dengan pesat, begitu pula dalam perkembangan pendidikan. Manusia secara sadar atau tidak sangat membutuhkan pendidikan untuk mengembangkan potensi dirinya melalui proses pembelajaran yang dapat berlangsung di dalam di luar sekolah. Pernyataan sesuai dengan yang termuat dalam Undang-undang No. 20 Tahun 2003 tentang Sistem 
Pendidikan Nasional Pasal 1 yang menyatakan bahwa Pendidikan adalah usaha sadar dan terencana untuk mewujudkan suasana belajar dan proses pembelajaran agar peserta didik secara spritual keagamaan, pengendalian diri, kepribadian, kecerdasan, akhlak mulia, serta keterampilan yang diperlukan dirinya, masyarakat, bangsa dan negara.

Pendidikan merupakan proses pembelajaran yang didapat oleh setiap manusia (peserta didik) untuk dapat membuat manusia (peserta didik) lebih kritis dalam berpikir. Salah satu dasar utama pendidikan adalah untuk mengajar kebudayaan melewati generasi.

Sudrajat (2003:12) mengatakan bahwa pembelajaran disekolah masih menggunakan pendekatan yang berpusat pada guru (teacher centered). Dalam pembelajaran tersebut guru cenderung menempatkan siswa sebagai objek, sehingga siswa menjadi pasif dalam proses pembelajaran.

Oleh karena itu kesempatan siswa untuk berperan aktif di dalam pembelajaran menjadi berkurang. Hal ini juga berdampak pada kurangnya kemampuan siswa untuk memahami materi pembelajaran, mengeluarkan ide ataupun pendapat, serta potensi yang dimiliki oleh siswa.

Rendahnya hasil belajar siswa juga dapat dipengaruhi oleh tidak bervariatifnya metode atau model pembelajaran yang dilakukan oleh guru. Kenyataan yang ada bahwa metode pembelajaran yang sering dilakukan oleh guru cenderung monoton dan siswa hanya mendegarkan saja materi tanpa ada umpan balik. Akibatnya pemikiran siswa kurang berkembang serta motivasi siswa dalam belajar menjadi kurang, sehingga peningkatan hasil belajar sulit dicapai. Siswa yang telah melalui proses belajar akan dihadapkan pada satu hal yaitu siswa diharapkan dapat mencapai tujuan pembelajaran yang disebut juga sebagai hasil belajar.
Keberhasilan dalam proses pembelajaran bahasa Indonesia tidak terlepas dari kegiatan peserta didik dan kesiapan pengajar (guru). Peserta didik dituntut mempunyai minat terhadap pelajaran bahasa Indonesia. Demikian juga pengajar dituntut menguasai materi yang akan diajarkan serta mampu memilih model, pendekatan, dan metode pembelajaran yang tepat sehingga akan tercipta interaksi eduktif yang baik menuju kearah peningkatan hasil belajar, karena hingga saat ini hasil belajar bahasa Indonesia masih rendah.

Berkaitan dengan hal tersebut, maka dituntut agar guru mata pelajaran khususnya mata pelajaran bahasa Indomesia selain menguasai materi pelajaran yang akan diajarkan juga harus dapat menciptakan Susana mengajar yang menyenangkan dan menggunakan metode dan model pembelajaran yang bervariatif, serta memberikan motivasi kepada siswa agar lebih berpartisipasi dalam mengikuti pembelajaran.

Model pembelajaran ialah pola yang digunakan sebagai pedoman dalam merencanakan pembelajaran di kelas maupun tutorial. Menutut Arends, model pembelajaran mengacu pada pendekatan yang akan digunakan, termasuk dalam kegiatan pembelajaran, lingkungan pembelajaran, dan pengelolaan kelas. Salah satu model pembelajaran yang dapat digunakan yaitu model pembelajaran kooperatif.

Hasil belajar bahasa Indonesia siswa yang kurang di SMA Negeri 10 Bulukumba, menunjukkan bahwa masih diperlukan perbaikan dalam proses pembelajaran, hal ini terlihat dengan nilai KKM yang diberikan sekolah yaitu 70 dan masih saja banyak siswa yang belum bisa mencapai nilai KKM tersebut. Keberhasilan siswa tidak terlepas dari kualitas pembelajaran yang dilakukan oleh guru, karena kualitas pembelajaran mempunyai hubungan berbanding lurus dengan hasil belajar siswa. 
Berdasarkan hasil observasi awal dan wawancara di SMA Negeri 10 Bulukumba, khususnya guru bahasa Indoensia mengemukakan bahwa selama ini proses pembelajaran yang diterapkan pada umumnya bersifat tradisional seperti ceramah, delikan, atau drill. minat belajar siswa pada pelajaran bahasa Indonesia masih kurang. Kurangnya minat siswa belajar bahasa Indonesia berdampak pada hasil belajar.

Peneliti memilih pelaksanaan penelitian di kelas XII IPA 1 karena pembelajaran bahasa Indonesia yang berjalan dikelas ini kami anggap siswa yang ada dikelas ini memiliki minat belajar yang kurang, sehingga dikhawatirkan pembelajaran yang diterima kurang membekas pada siswa. Adapun hasil observasi peneliti dalam pembelajaran bahasa Indonesia:

1. Pembelajaran masih terpusat pada guru

2. Model pembelajaran yang diterapkan oleh guru monoton, yaitu menggunakan model pembelajaran langsung

3. Metode pembelajaran yang diterapkan oleh guru monoton, yaitu menggunakan metode ceramah

4. Diskusi kelompok jarang sekali dilakukan sehingga interaksi siswa dengan siswa lain maupun dengan guru masih kurang terjalin selama proses pembelajaran,

5. Siswa masih merasa takut dan ragu untuk melontarkan pertanyaan atau pendapatnya kepada guru sehingga kelas menjadi kaku dan tidak aktif,

6. Hasil belajar siswa masih belum cukup optimal jika dilihat dari hasil evaluasi ulangan harian, 10 dari 24 jumlah siswa atau sekitar 27 persen siswa mendapatkan nilai dibawah KKM yang telah ditentukan di sekolah yaitu 75

Hal ini menjadikan siswa kurang aktif dalam menerima pembelajan bahasa
Indonesia sehingga dikhawatirkan pembelajaran yang diterima kurang membekas pada siswa. Model pembelajaran yang diterpkan oleh guru yang monoton dapat menjadikan siswa cepat merasa bosan dalam menerima pembelajaran bahasa Indonesia.

Dari hasil observasi tersebut, maka perlu kiranya sekolah mengembangkan suatu metode pembelajaran yang variatif sehingga mampu mengembangkan kreativitas dan memotivasi siswa. Saat ini banyak muncul metode-metode pembelajaran yang telah di kembangkan oleh para ahli filosof pendidikan. Salah satunya adalah pengembangan metode pembelajaran kooperatif yaitu "Question Student Have."

Metode Question Student Have adalah metode pembelajaran yang bertujuan untuk membuat siswa aktif sejak dini dalam mengikuti proses pembelajaran. Dengan menggunakan metode pembelajaran Question Student Have bisa menyemarakkan lingkungan belajar aktif dengan memberi siswa kesempatan untuk bergerak secara fisik, berbagi pendapat untuk mencapai sesuatu yang mereka banggakan. Strategi ini mewajibkan siswa menuliskan pertanyaan yang berupa soal atau masalah lain yang berhubung dengan materi yang belum dipahaminya dalam secarik kertas.

Berdasarkan latar belakang di atas, maka perlu kiranya dilakukan Penelitian Tindakan Kelas (PTK) mengenai penerapan pendekatan pembelajaran Kooperatif tipe Question Student Have, yang diharapkan dapat meningkatkan hasil belajar Bahasa Indonesia pada siswa Kelas XII IPA 1 SMA Negeri 10 Bulukumba.

\section{KAJIAN PUSTAKA}

\section{Pengertian Belajar dan Pembelajaran}

Belajar merupakan kegiatan bagi setiap orang yang dilandasi dengan adanya perubahan tingkah laku yang lebih baik. Belajar adalah suatu aktivitas atau suatu proses untuk memperoleh pengetahuan, 
meningkatkan keterampilan, memperbaiki perilaku, sikap, dan mengokohkan keperibadian. Menurut Gagne dalam Suprijono (2009:2) mengemukakan bahwa: "belajar adalah perubahan disposisi atau kemampuan yang dicapai seseorang melalui aktifitas. Perubahan disposisi tersebut bukan di peroleh langsung dari proses pertumbuhan seseorang secara alamiah."

Menurut L.B.Curzon dalam Sahabuddin (2007:80) mengemukakan definisi belajar yaitu sebagai modifikasi yang tampak dari perilaku seseorang melalui kegiatan-kegiatan dan pengalaman-pengalamannya, sehingga pengetahuan, keterampilan dan sikapnya, termaksuk penyesuaian cara-caranya, tahap lingkungan yang berubah-ubah, yang sedikit banyaknya permanen. Selanjutnya definisi ini diterapkan ke dalam pengertian sebagai kreasi dan pengawasan yang disengaja dan sistematik dari kondisi-kondisi yang didalamnya belajar berlangsung.

Leo Sutrisno dalam Suyono dkk (2012:13) mendefinisikan "belajar adalah suatu proses aktif menyusun makna melalui setiap interaksi dengan lingkungan, dengan membangun hubungan antara konsep yang telah dimiliki dengan fenomena yang sedang dipelajari." Sedangkan Slameto (2003:2) mengemukakan bahwa: "belajar adalah suatu perubahan tingkah laku, pengetahuan, keterampilan yang baru secara keseluruhan sebagai hasil dari pengalamannya sendiri dalam interaksi dengan lingkungannya".

Sadirman (2012:20) juga berpendapat bahwa belajar itu senantiasa merupakan perubahan tingkah lakuatau penampilan, dengan serangkaian kegiatan misalnya dengan membaca, mengamati, mendengarkan, meniru, dan lain sebagainya. Belajar itu akan lebih baik jika subjek belajar itu mengalami atau menggunakannya, tidak hanya bsrsifat herbalistik.

Jadi dari beberapa teori diatas dapat disimpulkan bahwa belajar pada dasarnya adalah perubahan seluruh tingkah laku individu yang relatif menetap sebagai hasil pengalaman dan interaksi dengan lingkungannya.

Pembelajaran terjemahan dari bahasa inggris "Instruction", terdiri dari dua kegiatan utama, yaitu: a) belajar (Learning) dan b) Mengajar (Teaching), kemudian disatukan dalam satu aktivitas, yaitu kegiatan belajar-mengajar yang selanjutnya popular dengan istilah pembelajaran (Intruction). Menurut Suherman dalam Jihad dkk (2013:11) “:pembelajaran pada hakikatnya merupakan proses komunikasi antara peserta didik dengan pendidik serta antara peserta didik dalam rangka perubahan sikap."

Konsep pembelajran menurut Corey dalam ( Syaiful, 2006 : 61) adalah suatu proses dimana lingkungan seseorang secara disengaja dikelola untuk memungkinkan ia turut serta dalam tingkah laku tertentu dalam kondisi - kondisi khusus atau menghasilkan respons terhadap situasi tertentu, pembelajaran merupakan subset khusus dari pendidikan.

Pembelajaran merupakan suatu proses yang terdiri dari kombinasi dua aspek, yaitu : belajar tertuju kepada apa yang harus dilakukan oleh siswa, mengajar berorientasi pada apa yang harus dilakukan oleh guru sebagai pemberi pembelajaran.

Menurut Komalasari (2013:3), pembelajaran adalah suatu sistem atau proses membelajarkan subjek didik/pembelajar yang direncanakan atau didesain, dilaksanakan, dan dievaluasi secara sistematis agar subjek didik/pembelajar dapat mencapai tujuantujuan pembelajaran secara efektif dan efisien.

Menurut Chaedar Alwasilah dalam Tim Pengembangan MKDP Kurikulum dan Pembelajaran (2011:181) "pembelajaran adalah sistem sosial tempat berlangsungnya mengajar dan belajar." Sedangkan menurut Tim Pengembangan MKDP Kurikulum dan Pembelajaran (2011:128) "pembelajaran adalah suatu upaya yang dilakukan oleh seorang guru atau pendidik untuk membelajarkan siswa yang belajar.“ 
Degeng dkk ( Haling, 2006 :14) mengatakan bahwa pembelajaran adalah suatu proses yang dilaksanakan secara sistematik di mana setiap komponen saling berpengaruh. Dalam proses secara implisit terdapat kegiatan memilih, menetapkan dan mengembangkan metode untuk mencapai hasil pembeljaran yang diinginkan. Pembelajaran menaruh perhatian pada bagaimana membelajarakan pebelajar dan lebih menekankan pada cara untuk mencapai tujuan.

\section{Pembelajaran Kooperatif}

Pembelajaran kooperatif adalah konsep yang lebih luas meliputi semua jenis kerja kelompok termasuk bentuk-bentuk yang lebih dipimpin oleh guru atau di arahkan oleh guru, dimana guru menetapkan tugas dan pertanyaan-pertanyaan serta menyediakan bahan-bahan dan informasi yang dirancang untuk membantu peserta didik menyelesaikan masalah yang dimaksud.

Menurut pendapat Roger dkk dalam Huda (2011:29), pembelajaran kooperatif merupakan aktivitas pembelajaran keompok yang diorganisir oleh satu prinsip bahwa pembelajaran harus didasarkan pada perubahan informasi secara sosial diantara kelompok-kelompok pembelajaran yang didalamnya setiap pembelajaran bertanggung jawab atas pembelajarannya sendiri dan didorong untuk meningkatkan pembelajaran anggota-anggota yang lain.

Menurut Komalasari (2013:62), pembelajaran kooperatif adalah suatu strategi pembelajaran dimana siswa belajar dan bekerja dalam kelompok kecil secara kolaboratif yang anggotanya terdiri dari 2 sampai 5 orang, dengan struktur kelompoknya yang bersifat heterogen.

Sedangkan Artz dan Newman dalam "Huda (2011:32)" mendefinisikan pembelajaran kooperatif sebagai kelompok kecil pembelajaran/siswa yang bekerja sama dalam satu tim untuk mengatasi suatu masalah, menyelesaikan sebuah tugas, atau mencapaisatu tujuan bersama.

Menurut Slavin (2005:5) "dalam metode pembelajaran kooperatif, para siswa akan duduk bersama dalam kelompok yang beranggotakan 4 orang untuk menguasai materi yang disampaikan oleh guru."

Menurut Slavin (2005:5) menyatakan bahwa ada lima perspektif teoritis yang mendasari pembelajaran kooperatif ini yaitu :

1. Persektif Motivasional (motivational perspective)

2. Perspektif kohesi social (social cohesion perspective)

3. Perspektif kognitif (cognitive perspective)

4. Perspektif perkembangan (developmental perspective)

5. Perspektif elaborasi kognitif cognitive elaboration perspective)

Menurut Ibrahim dkk dalam Suprihatiningrum (2013:193). Langkahlangkah Model Pembelajaran Kooperatif yaitu :

Tabel 1 Langkah- langkah pembelajaran kooperatif

\begin{tabular}{|c|c|}
\hline Fase & Tingkah Laku Guru \\
\hline $\begin{array}{l}\text { 1. Menyampaikan tujuan } \\
\text { dan memotivasi } \\
\text { peserta didik }\end{array}$ & $\begin{array}{l}\text { Guru menyampaikan } \\
\text { semua } \\
\text { pembelajaran tujuan } \\
\text { ingin dicapai pada } \\
\text { pelajaran tersebut dan } \\
\text { memotivasi peserta } \\
\text { didik belajar }\end{array}$ \\
\hline 2. Menyajikan informasi & $\begin{array}{lr}\text { Guru menyajikan } \\
\text { informasi kepada } \\
\text { peserta didik dengan } \\
\text { jalan demonstrasi atau } \\
\text { lewat bahan bacaan. }\end{array}$ \\
\hline $\begin{array}{l}\text { 3. Mengorganisasikan } \\
\text { peserta didik ke dalam } \\
\text { kelompok-kelompok } \\
\text { belajar }\end{array}$ & $\begin{array}{lr}\text { Guru } & \text { menjelaskan } \\
\text { kepada peserta didik } \\
\text { bagaimana caranya } \\
\text { membentuk } & \text { kelompok } \\
\text { belajar } & \text { agar } \\
\text { melakukan } & \text { transisi } \\
\text { secara efisien } & \end{array}$ \\
\hline $\begin{array}{l}\text { 4. Membimbing } \\
\text { kelompok bekerja dan } \\
\text { belajar }\end{array}$ & $\begin{array}{l}\text { Guru membimbing } \\
\text { kelompok-kelompok } \\
\text { belajar pada saat } \\
\text { mereka mengerjakan }\end{array}$ \\
\hline
\end{tabular}




\begin{tabular}{ll}
\hline & tugas mereka \\
5. Evaluasi & Guru mengevaluasi \\
& hasil belajar tentang \\
& materi yang telah \\
& dipelajari atau masing- \\
& masing kelompok \\
& mempresentasikan \\
& hasil kerjanya. \\
& Guru mencari cara- \\
& cara untuk menghargai \\
& baik upaya maupun \\
6. Memberikan & danil belajar individu \\
penghargaan &
\end{tabular}

Sumber :Strategi Pembelajaran_(2013:193)

\section{Pembelajaran Kooperatif tipe Question Students Have}

Metode Question Student Have adalah metode pembelajaran yang bertujuan untuk membuat siswa aktif sejak dini dalam mengikuti proses pembelajaran. Metode ini merupakan suatu cara yang mudah untuk mempelajari pemikiran dan keinginan siswa. Metode ini menggunakan suatu teknik untuk mewujudkan partisipasi siswa melalui pemikiran-pemikiran atau ide-ide yang dituangkan dalam pertanyaan atau tulisan yang dimiliki oleh siswa tentang materi pembelajaran.

Agus Suprijono (2009) menerangkan langkah- langkah pembelajaran koeratif Question Student Have yaitu:

a. Pembelajaran dengan metode ini diawali dengan membagi kelas menjadi empat (4) kelompok.

b. Bagikan kertas kosong kepada setiap peserta didik dalam setiap kelompok.

c. Dalam tiap kelompok, putarlah kartu tersebut searah jarum jam. Ketika setiap kartu diedarkan pada anggota kelompok, anggota tersebut harus membacanya

d. Memberikan tanda (v) jika pertanyaan tersebut dianggap penting. Perputaran berhenti sampai kartu sampai kartu tersebut kembali pada pemiliknya masing-masing.

Fakultas Keguruan dan Ilmu Pendidikan

Universitas Bosowa Makassar e. Setiap pemilik kartu dalam kelompok harus memeriksa pertanyaanpertanyaan mana yang mendapat suara terbanyak. Setelah itu jumlah perolehan suara atas pertanyaan itu dibandingkan dengan perolehan anggota lain dalam satu kelompok.

f. Setiap kelompok melaporkan secara tertulis pertanyaan yang telah menjadi milik kelompok (mewakili kelompok).

g. Guru melakukan pemeriksaan terhadap pertanyaan dari tiap-tiap kelompok.

Menurut Hartono dalam nicaturisma.files.wordpress.com (diakses pada tanggal 11 desember 2012) model pembelajaran Question Students Have memiliki kelebihan sebagai berikut:

1. Pelaksanaan proses pembelajaran ditekankan pada keaktifan belajar siswa dan keaktifan guru dalam menciptakan lingkungan belajar yang serasi dan menantang pola interaksi siswa.

2. Siswa termotivasi dalam belajar dan siswa akan mendapat kemudahan dalam menerima dan memahami materi yang diajarkan karena terjadi timbal balik antara guru dan siswa.

3. Mendapat partisipasi siswa melalui tulisan, sehingga sangat baik bagi siswa yang kurang berani mengungkapkan pertanyaan, keinginan, dan harapan-harapan melalui percakapan.

4. Siswa tidak hanya mendengarkan tetapi perlu membaca, menulis, berdiskusi dan mendorong siswa untuk berfikir dalam memecahkan suatu soal.

5. Dapat menjaga perhatian siswa agar tetap tertuju pada proses pembelajaran, memperkuat dan memperlancar stimulus respon siswa, sehingga pembelajaran lebih menyenangkan dan mampu memberi 
kesan yang mendalam pada diri siswa.

6. Guru lebih mengetahui dimana letak ketidakpahaman siswa, karena semua siswa sudah mengajukan pertanyaan dan akan didiskusikan.

\section{Hasil Belajar}

Hasil belajar adalah pola-pola perbuatan, nilai-niai, pengertian-pengertian, sikap-sikap, apresiasi dan keterampilan. Menurut Jihad dkk (2013:14), bahwa, hasil belajar pencapaian bentuk perubahan prilaku yang cenderung menetap dari rana kognitif, efektif, dan pisikomotoris dari proses belajar yang dilakukan dalam waktu tertentu. Dan menurut Juliah dalam Jihad dkk (2013:15), hasil belajar adalah segala sesuatu menjadi milik siswa sebagai akibat dari kegiatan belajar yang dilakukannya. Adapun menurut Sudjana dalam Jihad dkk (2013:15), hasil belajar adalah kemampuan-kemampuan yang dimiliki siswa setelah ia menerima pengalaman belajar.

(Kustawan, dkk.2013:14) mendefinisikan Hasil belajar adalah kompetensi atau kemampuan yang diperoleh peserta didik berkebutuhan khusus setelah melalui kegiatan belajar. Kegiatan belajar merupakan satu kesatuan dengan kegiatan mengajar. Belajar itu sendiri merupakan suatu proses dari peserta didik berkebutuhan khusus yang berusaha untuk memperoleh suatu bentuk perubahan perilaku yang relatif menetap sesuai dengan karakteristiknya dan kebutuhan khususnya.

Menurut Benjamin S. Bloom dalam Jihad dkk (2013:14-15), hasil belajar dapat dikelompokkan dalam dua macam yaitu pengetahuan dan keterampilan. Pengetahuan terdiri dari empat kategori, yaitu :

1) Pengetahuan tentang fakta

2) pengetahuan tentang prosedural

3) pengetahuan tentang konsep dan

4) pengetahuan tentang prinsip
Keterampilan juga terdiri dari empat kategori, yaitu;

1) keterampilan untuk berpikir atau keterampilan kongnitif

2) keterampilan untuk bertindak atau keterampillan motorik

3) keteramilan beraksi atau bersikap dan

4) keterampilan berinteraksi.

Dari beberapa pendapat yang menjelaskan tentang hasil belajar kita dapat memahami bahwa hasil belajar akan diperoleh setelah melalui suatu proses. Hasil belajar dapat berupa pengetahuan, keterampilan maupun sikap. Hasil belajar merupakan efek yang ditimbulkan dari kegiatan belajar.

Merujuk pemikiran Gagne dalam Suprijono (2009:5), hasil belajar berupa:

1. Informasi verbal yaitu kapabilitas mengungkapan dalam bentuk bahasa, baik lisan maupun tertulis.

2. Keterampilan intelektual yaitu kemampuan mempresentasikan konsep dan lambing.

3. Strategi kognitif yaitu kecakapan menyalurkan dan megarahkan aktifitas kognitifnya sendiri.

4. Keterampilan motorik yaitu kemampuan melakukan serangkaian gerak jasmani dalam urusan dan koordinasi, sehingga terwujud otomatisme gerak jasmani.

5. Sikap adalah kemampuan menerima atau menolak objek berdasarkan penilaian terhadap objek tersebut.

Menurut Bloom dalam Suprijono (2009:6) Hasil belajar mencakup kemampuan kognitif, afektif, dan pesikomotorik. Domain kognitif adalah knowledge (pengetahuan ingatan), comprehension (pemahaman, menjelaskan, meringkas, contoh), application (menerapkan), analysis (menguraikan, merencanakan, membentuk bagunan baru), dan evaluation (menilai).

Kemampuan kognitif adalah kemampuan yang mencakup kegiatan mental. Kemampuan afektif adalah kemampuan 
yang berkaitan degan sikap dan nilai. Dan kemampuan pesikomotorik adalah kemampuan yang berkaitan degan keterampilan (skill) atau kemampuan bertindak setelah seseorang menerima pengalaman belajar tertentu.

\section{METODE PENELITIAN}

Penelitian ini merupakan penelitian tindakkan kelas (classroom action research). Penelitian ini terdiri atas serangkaian siklus, setiap siklus meliputi empat tahap yaitu : perencanaan, pelaksanaan tindakan, observasi dan refleksi. Subjek dalam penelitian ini adalah siswa kelas XII IPA 1 SMA Negeri 10 Bulukumba tahun pelajaran 2017/2018 semester genap yang berjumlah sebanyak 24 siswa, terdiri dari 5 siswa lakilaki dan 19 siswa perempuan. Adapun Instrumen yang digunakan dalam penelitian ini adalah Lembar observasi dan test. Teknik analisis data yang digunakan dalam penelitian ini menggunakan analisis data deskriptif kualitatif. Analisis data kualitatif digunakan untuk mengolah data hasil observasi guru dan siswa. Adapun teknik data deskriptif kualitatif digunakan untuk menghitung presentase nilai rata - rata. Kriteria Ketuntasan Minimal (KKM) yang diterapkan pada mata pelajaran Fisika adalah 75. Jadi nilai siswa dapat dikatakan tuntas apabila mencapai nilai KKM (Kriteria Ketuntasan Minimal).

\section{HASIL PENELITIAN DAN PEMBAHASAN}

\section{Hasil Penelitian}

Pada bab ini dibahas secara rinci mengenai hasil belajar Bahasa Indonesia siswa Kelas XII IPA 1 SMA Negeri 10 Bulukumba dengan menggunakan model pembelajaran Question Student Have. Dari siklus I ke siklus II dengan menggunakan analisis kualitatif dan kuantitatif. Hasil analisis kualitatif dilakukan berdasarkan observasi pada saat proses pembelajaran berlangsung di kelas terhadap model pembelajaran Question Student Have. Sedangkan data mengenai hasil belajar di analisis secara kuantitatif dengan menggunakan statistik deskriptif, yaitu skor rata-rata, persentase, persentase nilai terendah, persentase nilai tertinggi dan rentang nilai yang di capai peserta didik setiap siklus. Adapun yang akan di analisis adalah hasil tes sebelum tindakan, tes siklus I dan tes siklus II. Hasil penelitian dan pembahasan data penelitian diuraikan sebagai berikut.

\section{Analisis Hasil belajar Bahasa Indonesia Siswa Sebelum Pelaksanaan Tindakan}

Sebelum pelaksanaan tindakan terlebih dahulu siswa diberikan tes kemampuan awal sebagai dasar pengambilan keputusan untuk menuju ketahap tindakan. Tes kemampuan awal diberikan pada pertemuan pertama sebelum memulai pembelajaran dengan model Question Student Have. Tes kemampuan awal ini dalam bentuk Essai. Nilai hasil pemberian tes kemampuan awal yang menunjukkan hasil belajar Bahasa Indonesia siswa Kelas XII IPA 1 SMA Negeri 10 Bulukumba sebelum penerapan model pembelajaran Question Student Have dapat dilihat pada tabel dibawah ini:

Tabel 2 Statistik Skor Hasil Belajar Bahasa Indonesia Siswa Kelas XII IPA 1 SMA Negeri 10 Bulukumba Sebelum Pelaksanaan Tindakan

\begin{tabular}{cc}
\hline Statistik & Nilai Statistik \\
\hline Subjek & 24 \\
Skor ideal & 100 \\
Skor tertinggi & 80 \\
Skor terendah & 25 \\
Rentang skor & 60 \\
Skor rata-rata & 48,5 \\
\hline
\end{tabular}

Sumber : Olah Data Hasil Belajar Siswa, 2018

Jika skor siswa dikategorikan kedalam pengkategorian hasil belajar maka akan tampak pada tabel berikut ini : 
Tabel 3 Distribusi Frekuensi Dan Persentase Skor Hasil Belajar Bahasa Indonesia Siswa Kelas XII IPA 1 SMA Negeri 10 Bulukumba Sebelum Tindakan

\begin{tabular}{lcccc}
\hline No & Skor & Kategori & Frekuensi & \\
\hline & $0-34$ & Sangat & & \\
1. & $35-54$ & Rendah & 7 & \\
2. & $55-64$ & Rendah & 7 & \\
3. & $65-84$ & Sedang & 7 & \\
4. & $84-$ & Tinggi & 3 & \\
5. & 100 & Sangat & 0 & $\mathbf{1 0 0}$ \\
\hline \multicolumn{5}{c}{ Jumlah } \\
\hline
\end{tabular}

Sumber : Olah Data Hasil Belajar Siswa, 2018

Dari tabel 2 dan 3 dapat disimpulkan bahwa hasil belajar bahasa Indonesia siswa Kelas XII IPA 1 SMA Negeri 10 Bulukumba sebelum pelaksanaan tindakan pembelajaran Question Student Have. Di peroleh data untuk nilai tertinggi adalah 80 dan nilai terendah 20, serta rata-rata hasil belajar sebesar 48,5. Berdasarkan tabel tehnik kategorisasi perolehan hasil belajar siswa sebelum tindakan model pembelajaran Question Student Have 7 siswa berada pada kategori sangat rendah, 7 siswa berada pada kategori rendah, 7 siswa berada pada kategori sedang, 3 siswa berada pada kategori tinggi, dan belum ada peserta yang berada pada kategori sangat tinggi.

Apabila hasil belajar siswa pada saat sebelum tindakan dianalisis sesuai standar ketuntasan yang di berikan oleh sekolah, maka persentase ketuntasan belajar siswa dapat dilihat pada tabel 4.3 berikut:

Tabel 4 Deskripsi Ketuntasan Belajar Siswa Kelas Kelas XII IPA 1 SMA Negeri 10 BulukumbaSebelum tindakan

\begin{tabular}{cccc}
\hline No & $\begin{array}{c}\text { Interval } \\
\text { skor }\end{array}$ & Kategori & Frekuensi \\
\hline 1 & $0-74$ & Tidak & 21 \\
2 & $75-100$ & tuntas & 3 \\
& & Tuntas & \\
\hline
\end{tabular}

Sumber : Olah Data Hasil Belajar Siswa, 2018

Dari tabel 4 di atas menunjukkan bahwa pada saat tes sebelum tindakan dilakukan persentase ketuntasan belajar sebesar 3 dari 24 siswa termasuk dalam kategori tuntas dan 21 dari 24 siswa termasuk dalam kategori tidak tuntas. Hal ini memberikan indikator bahwa proses pembelajaran belum tercapai tujuan yang diharapkan guru yang tertuang dalam indikator kinerja 85 persen dari jumlah siswa dalam kelas telah mencpai ketuntasan individual, sehingga perlu dilaksanakan model pembelajaran yang kebih kreatif dan menyenangkan sehingga hasil belajar peserta didik dapat meningkat.

\section{Analisis Hasil Belajar Bahasa Indonesia Siswa Pada Siklus I \\ a. Perencanaan}

Pada tahap perencanaan siklus I pendidik membaut skenario pembelajaran Bahasa Indonesia kelas XII IPA 1 semester II pada satuan Pendidikan SMP Siklus I dilaksanakan selama tiga kali pertemuan sudah termasuk Tes hasil belajar. Setelah itu pendidik membuat rencana pelaksanaa pembelajaran (Rpp) dengan model Question Student Have yang menjadi pedoman pendidik dalam melaksanakan pembelajran di kelas dan lembar pengamatan aktivitas siswa yang menunjang pelaksanaan pembelajaran dengan menggunakan model pembelajaran Question Student Have. Lembar pengamatan dibuat untuk mengetahui sejauh mana interaksi siswa pada saat proses pembelajaran. Selain itu disusun juga lembar pengamatan aktifitas pendidik dalam melaksanakan pembelajaran dengan menggunakan model pembelajaran Question Student Have.

Untuk menilai hasil pelaksanaan pembelajaran pada siklus I, pendidik menganalisis dan menyeleksi soal-soal yang akan diberikan kepada siswa serta menerapkan model pembelajaran Question Student Have. Analisis tes hasil belajar ini bertujuan untuk mengukur peningkatan hasil pembelajaran bahasa Indonesia menggunakan model pembelajaran Question Student Have selama siklus I. 


\section{b. Pelaksanaan Tindakan Siklus I}

Pelaksanaan tindakan siklus I dilaksanakan 3 kali pertemuan, seperti yang telah direncanakan yaitu tanggal 28 Januari sampai 11 Februari 2018 dan pada tanggal 11 Februari 2018 dilaksanakan tes siklus I di Kelas XII IPA 1 SMA Negeri 10 Bulukumba. Pertemuan siklus I dilaksanakan selama 4 x 45 menit, dimana masing masing pembahasan pokok materi dilaksanakan selama 2 x 45 menit, Sesuai dengan skenario pembelajaran dan Rpp. Kegiatan yang dilakukan antara lain pendidik menyampaikan teknik pembelajaran Kooperatif Tipe Question Student Have yang akan diterapkan pada proses pembelajaran. Pendidik mengecek kehadiran siswa. Pendidik juga menyampaikan kompetensi dasar dan tujuan pembelajaran.

Pendidik membagi siswa dalam 4 kelompok, dimana setiap kelompok terdiri dari 5 peserta didik yang memiliki kemampuan akademik yang heterogen. Pembagian kelompok yang heterogen siswa akan lebih mudah untuk memahami materi yang sulit sehingga dapat berdiskusi dengan teman sekelompoknya. Setelah pembagian kelompok, siswa dalam tiap-tiap kelompok menuliskan pertanyaan mengenai materi pembelajaran yang telah diberikan oleh pendidik dalam selembar kertas.

Setelah siswa membuat pertanyaan, setiap peserta memutar lembar pertanyaannya kepada tiap anggota kelompoknya searah jarum jam. Setelah diputar, tiap siswa mengecek pertanyaan mana yang dianggap penting. Dan diputar lagi, sampai siswa mendaptkan kembali kertas miliknya. Setelah semua jawaban di cek, setiap kelompok berdiskusi untuk menyimpulkan pertanyaan mana yang akan menjadi milik kelompok, untuk di berikan kepada pendidik. Setelah semua pertanyaan dari tiap-tiap kelompok terkumpul, pendidik dan siswa membahas bersama pertanyaan yang telah dibuat dan dikumpulkan oleh siswa. Setelah pembelajaran selesai, pendidik menutup pembelajaran dengan memberikan kesimpulan terkait materi yang dibahas dan menyuruh siswa belajar dirumah untuk mempelajari materi yang akan di bahas pada pertemuan selanjutnya. Langkah terakhir dalalm pelaksanaan tindakan kelas ini pendidik memberikan soal evaluasi tes individu sebagai tes akhir siklus I yang berbentuk Essai.

\section{c. Hasil Observasi dan Evaluasi \\ 1) Hasil Analisis Kualitatif}

Data kualitatif merupakan data tentang sikap siswa kelas VIII $_{4}$ SMA Negeri 10 Bulukumba dalam mengikuti model pembelajaran Question Student Have yang diperoleh melalui lembar observasi siswa dan pendidik. Pengamatan dilakukan dengan menggunakan lembar pengamatan siswa dan pendidik yang telah dibuat oleh peneliti. Hasil pengamatan dengan menggunakan Pembelajaran Question Student Have pada Siklus I diperoleh hasil sebagai berikut :

\section{a. Pertemuan I}

Pada pertemuan I diawali dengan memperkenalkan pembelajaran Kooperatif Tipe Question Student Have pada siswa, setelah itu kemudian membagi siswa ke dalam beberapa kelompok. Sebagian siswa mulai antusias belajar dengan pembelajaran Kooperatif Tipe Question Student Have, karena mereka dapat berdiskusi dan bertukar pendapat dengan teman kelompoknya mengenai pertanyaan mana yang dapat mereka ajukan, tetapi pada pertemuan I ini masih banyak juga siswa yang melakukan aktivitas lain ketika proses pembelajaran Kooperatif Tipe Question Student Have ini di terapkan. Dan situasi kelas pada saat proses belajar mengajar berlangsung masih belum bisa dikontrol oleh pendidik. Namun adapun siswa yang merasa bersemangat karena suasana lingkungan belajar yang lebih menyenangkan dan baru.

\section{b. Pertemuan II}

Pada pertemuan II, jumlah siswa yang memperhatikan pelajaran masih sama pada pertemuan I akan tetapi mereka mulai tidak 
mengganggu temannya yang belajar. Dan pada saat pertemuan II ini, kelas sudah mulai bisa di control oleh pendidik, siswa diarahkan untuk lebih tenang. Namun masih ada saja siswa yang masih melakukan hal lain. Kendala lain yang dihadapi yaitu kurangnya konsentrasi siswa dalam membuat pertanyaan dan masih banyak yang mengemukakan pertanyaan yang monoton atau kurang bervariasi. Dan kurangnya minat siswa untuk berpartisipasi untuk menjawab pertanyaan yang telah di buat. Serta masih kurangnya percaya diri siswa untuk menyimpulkan materi yang telah dibahas bersama.

\section{c. Pertemuan III}

Pertemuan III merupakan pertemuan terakhir dalam siklus I, kegiatan ini telah menemukan bentuk tersendiri sesuai dengan yang dikehendaki peneliti. Pada pertemuan ini, terlihat kegiatan peneliti cenderung mulai lebih baik dibanding dengan pertemuan I dan II. Dan situasi kelas lebih teratur dibandingkan dengan pertemuan I dan pertemuan II. Berdasarkan pemantauan dari peneliti, pada pertemuan tersebut jumlah siswa yang memahami materi dengan pembelajaran Kooperatif Tipe Question Student Have mengalami peningkatan dari tiap pertemuan.

Meskipun demikian pada proses pembelajaran masih ada sebagian siswa yang pasif saat pemberian tugas kelompok, bahkan mereka masih sering melakukan aktivitas lain, bahkan menganggu teman kelompoknya yang lain. Siswa tersebut masih perlu mendapatkan bimbingan baik di kelas maupun di luar kelas.

Berikut tabel hasil aktivitas belajar siswa selama pembelajaran siklus I sebagai berikut:

Tabel 5 Data Hasil Observasi Kegiatan Siswa kelasKelas XII IPA 1 SMA Negeri 10 BulukumbaSiklus I

\begin{tabular}{ccc}
\hline No & Kualifikasi & $\begin{array}{c}\text { Presentase } \\
\text { Keberhasilan \% }\end{array}$ \\
\hline 1 & Baik & 80,30
\end{tabular}

\begin{tabular}{ccc}
2 & Cukup & 19,70 \\
3 & Kurang & 0,00 \\
\hline & Jumlah & $\mathbf{1 0 0}$
\end{tabular}

Sumber: Hasil analisis 2018

Berdasarkan tabel 5 diatas maka dapat diketahui bahwa dari keseluruhan kegiatan menunjukkan bahwa presentase kegiatan siswa pada siklus I menunjukkan 80.30 persen siswa berkelakuan baik, 19.70 persen siswa berkelakuan cukup, dan tidak ada siswa yang berkelakuan kurang. Dari tabel diatas dapat di simpulkan bahwa siswa yang mengikuti kegiatan belajar dengan baik setelah penerapan model sudah melebihi setegah dari jumlah siswa.

\section{2) Hasil Data Kuantitatif}

Pada akhir siklus I diadakan tes hasil belajar yang berbentuk ulangan harian setelah penyajian satu pokok bahasan. Evaluasi tes hasil belajar ini bertujuan untuk melihat peningkatan kemampuan pemahaman siswa terhadap materi yang telah diberikan. Adapun data skor hasil belajar siswa dari tes Siklus I dapat dilihat pada Tabel 6 berikut :

Tabel 6 Statistik Skor Hasil Belajar Bahasa Indonesia Pada Siklus I

\begin{tabular}{cc}
\hline Statistik & Nilai Statistik \\
\hline Subjek & 24 \\
Skor ideal & 100 \\
Skor tertinggi & 85 \\
Skor terendah & 40 \\
Rentang skor & 45 \\
Skor rata-rata & 66,70 \\
\hline
\end{tabular}

Sumber : Olah Data Hasil Belajar Siswa, 2018

Apabila skor hasil belajar pada tabel di atas di kelompokkan ke dalam lima kategori, maka diperoleh distribusi frekuensi skor seperti ditunjukkan tabel berikut : 
Tabel 7 Distribusi Frekuensi Dan Persentase Skor

Hasil Belajar Bahasa Indonesia Siklus I

\begin{tabular}{cccc}
\hline No & Skor & Kategori & Frekuensi \\
\hline 1. & $0-34$ & Sangat & 0 \\
2. & $35-54$ & Rendah & 4 \\
3. & $55-64$ & Rendah & 8 \\
4. & $65-84$ & Sedang & 11 \\
5. & $84-100$ & Tinggi & 1 \\
\multicolumn{3}{c}{ Sangat Tinggi } \\
\hline \multicolumn{3}{c}{ Jumlah } \\
\hline
\end{tabular}

Sumber : Olah Data Hasil Belajar Siswa, 2018

Berdasarkan table 7 di atas, dapat disimpulkan bahwa dari 24 siswa kelas, tidak terdapat siswa yang berada pada kategori sangat rendah, terdapat 4 siswa yang tingkat hasil belajar Bahasa Indonesianya pada kategori rendah, pada kategori sedang sekitar 8 siswa, pada kategori tinggi 11 siswa, serta 1 siswa yang tingkat hasil belajar Bahasa Indonesianya berada pada kategori sangat tinggi.

Apabila hasil belajar siswa pada siklus I dianalisis sesuai standar ketuntasan yang di berikan oleh sekolah, maka persentase ketuntasan belajar siswa pada siklus I dapat dilihat pada tabel 8 berikut:

Tabel 8 Deskripsi Ketuntasan Belajar Siswa Kelas XII IPA 1 SMA Negeri 10 Bulukumba Siklus I

\begin{tabular}{cccc}
\hline No & Interval skor & Kategori & F \\
\hline 1 & $0-74$ & Tidak tuntas \\
2 & $75-100$ & Tuntas \\
\hline
\end{tabular}

Sumber : Olah Data Hasil Belajar Siswa, 2018

Dari tabel 8 di atas menunjukkan bahwa pada siklus I persentase ketuntasan belajar sebesar 50 persen yaitu 12 dari 24 siswa termasuk dalam kategori tuntas dan 50 persen atau 12 dari 12 siswa termasuk dalam kategori tidak tuntas. Artinya tes siklus I bisa dikatakan meningkat, akan tetapi persentase ketuntasannya belum mencapai kriteria ketuntasan minimal (KKM) yang telah ditetapkan. Siswa yang belum mencapai tingkat ketuntasan perlu diberikan perbaikan atau pengayaan berupa tatap muka secara individual yang dilakukan oleh pendidik pada jam istirahat dan meminta kepada siswa yang telah mencapai ketuntasan belajar untuk membimbing teman kelompoknya yang belum tuntas belajarnya serta memberikan tugas tambahan berupa soal-soal untuk dikerjakan dirumah.

\section{d. Refleksi}

Berdasarkan hasil obsrvasi siklus I yang meruapakan siklus awal dalam penelitian tindakan kelas ini diperoleh data bahwa masih ada siswa yang peoses belajarnya belum optimal, belum terlihat adanya perkembangan yang cukup memuaskan tetapi keaktifan siswa dalam pembelajaran dari setiap pertemuan mengalami peningkatan, tapi peningkatan tersebut hasilnya belum maksimum sehingga perlu adanya perbaikan-perbaikan yang mengarah pada perkembangann yang cukup baik.

Berdasarkan hasil perolehan dari pelaksanaan siklus I, maka hasil terdapat hal-hal yang perlu diperhatikan dan diperbaiki sesuai dengan pencapaian indikator yang harus di capai dalam penelitian, yakni siswa harus bekerja sama dalam kelompok, harus bisa bertanya dan Frekupisituab persentasen (\%) dan memberikan tanggapan yang 50baik kepada temantehhannya. Keseriffsan siswa pada saat boqlangsung pempodajaran masih kurang pada siklus I

Berdasarkan hasil observasi dan refleksi setelah pelaksanaan siklus I terlihat bahwa hasil belajar Bahasa Indonesia siswa Kelas XII IPA 1 SMA Negeri 10 Bulukumba setelah diberi tindakan pada Siklus I berada pada kategori sedang dengan skor rata-rata 66,70 dari skor ideal 100. Oleh karena itu pendidik ingin meningkatkan lagi hasil belajar siswa. Maka pendidik mengadakan lagi siklus II. 


\section{Analisis Hasil Belajar Bahasa Indonesia Siswa Pada Siklus II \\ a. Perencanaan}

Pada tahap perencanaan ini sama halnya dengan siklus I, yakni pendidik menyiapkan skenario pembelajaran dan membahas kembali materi kebijakan pemerintah dalam bdaing Bahasa Indonesia. Sebagaimana yang dipaparkan pada bab III bahwa perencanaan dan pelaksanaan tindakan pada siklus II ini pada dasarnya mengulang langkah -langkah siklus I. Namun yang berbeda adalah pada siklus II dilakukan penyempurnaan dan perbaikan terhadap kendala-kendala atau kelemahan-kelemanhan yang muncul pada siklus I.

\section{b. Pelaksanaan Tindakan}

Pelaksanaan Tindakan II dilaksanakan dalam 3 kali pertemuan yang telah direncanakan yaitu tangal 18 Februari sampai tanggal 4 maret 2018 dan tanggal 4 maret 2018 diadakan tes hasil belajar siklus II di ruang Kelas XII IPA 1 SMA Negeri 10 Bulukumba. Pertemuan pada siklus II dilaksanakan selama 4 x 45 menit, dimana masing - masing pembahasan pokok materi dilaksanakan selama 2 x 45 menit, Sesuai dengan skenario pembelajaran dan Rpp. Kegiatan yang dilakukan antara lain pendidik menyampaikan tehnik pembelajaran Kooperatif Tipe Question Student Have yang akan diterapkan pada proses pembelajaran dan menjelaskan materi Bahasa Indonesia. Pendidik mengecek kehadiran siswa. Pendidik juga menyampaikan kompetensi dasar dan tujuan pembelajaran.

Pendidik membagi siswa dalam 4 kelompok, dimana setiap kelompok terdiri dari 8 peserta didik yang memiliki kemampuan akademik yang heterogen dan menentukan ketua kelompok yang dianggap yang memiliki kemampuan akademik yang tinggi. Pembagian kelompok yang heterogen siswa akan lebih mudah untuk memahami materi yang sulit sehingga dapat berdiskusi dengan teman sekelompoknya. Setelah pembagian kelompok, siswa dalam tiap-tiap kelompok menuliskan pertanyaan mengenai materi pembelajaran yang telah diberikan oleh pendidik dalam selembar kertas.

Setelah siswa membuat pertanyaan, setiap peserta memutar lembar pertanyaannya kepada tiap anggota kelompoknya searah jarum jam. Setelah diputar, tiap siswa mengecek pertanyaan mana yang dianggap penting. Dan diputar lagi, sampai siswa mendaptkan kembali kertas miliknya. Setelah semua jawaban di cek, setiap kelompok berdiskusi untuk menyimpulkan pertanyaan mana yang akan menjadi milik kelompok, untuk di berikan kepada pendidik. Setelah semua pertanyaan dari tiap-tiap kelompok terkumpul, pendidik dan peserta didik membahas bersama pertanyaan yang diberikan oleh peserta didik. Setelah pembelajaran selesai, pendidik menutup pembelajaran dengan memberikan kesimpulan terkait materi yang dibahas dan menyuruh peserta didik belajar dirumah untuk mempelajari materi yang akan di bahas pada pertemuan selanjutnya.Langkah terakhir dalalm pelaksanaan tindakan kelas ini pendidik memberikan soal evaluasi tes individu sebagai tes akhir siklus II yang berbentuk Essai.

\section{c. Hasil Observasi dan Evaluasi \\ 1) Hasil Analisis Kualitatif}

Data kualitatif merupakan data tentang sikap siswa Kelas XII IPA 1 SMA Negeri 10 Bulukumba dalam mengikuti model pembelajaran Question Student Have yang diperoleh melalui lembar observasi peserta didik dan pendidik. Pengamatan dilakukan dengan menggunakan lembar pengamatan peserta didik dan pendidik yang telah dibuat oleh peneliti. Hasil pengamatan dengan menggunakan Pembelajaran Question Student Have pada Siklus II diperoleh hasil sebagai berikut :

\section{a. Pertemuan IV}

Pada pertemuan ini, motivasi siswa untuk memahami materi terus bertambah. Siswa mulai berani bertanya jika ada hal-hal yang mereka anggap belum memahaminya baik 
kepada teman kelompoknya maupun langsung pada guru. Situasi kelas juga telah bisa di kontrol dengan baik oleh pendidik dan siswa sudah mulai teratur. dan siswa lebih aktif dalam proses belajar mengajar, baik dalam kelompok maupun pada saat diskusi. Prioritas peneliti dalam penelitian ini, diutamakan agar siswa yang hasil belajarnya masih rendah pada siklus I dapat meningkat.

\section{b. Pertemuan V}

Pada pertemuan $\mathrm{V}$, rasa percaya diri siswa mulai meningkat. Siswa sudah mulai berkonsentrasi dalam membuat pertanyaan dan siswa sudah mulai mengemukakan pertanyaan - pertanyaan yang bervariasi. siswa juga sudah mengerti apa yang harus dilakukan, tanpa ada arahan dari pendidik, serta meningkatnya minat siswa untuk berpartisipasi dalam menjawab pertanyaan yang telah di buat. Dan siswa tidak canggung lagi untuk mengemukakan pendapatnya dalam diskusi.

\section{c. Pertemuan VI}

Pada pertemuan yang terakhir ini, sudah tidak terlihat lagi kendala dalam penelitian ini. Keaktifan siswa dalam belajar, keseriusan dalam belajar, siswa tidak canggung lagi untuk mengemukakan pendapatnya dalam diskusi. Situasi kelas juga sudah teratur, siswa juga sudah tertib dalam mengikuti proses belajar mengajar. Dan lebih berkonsentrasi lagi dalam membuat pertanyaan dan mengemukakan pertanyaan - pertanyaan yang bervariasi.

Berikut dipaparkan tabel hasil aktivitas belajar siswa selama pembelajaran siklus II:

Tabel 9 Data Hasil Observasi Kegiatan Siswa Kelas XII IPA 1 SMA Negeri 10 Bulukumba Siklus II

\begin{tabular}{ccc}
\hline No & Kualifikasi & $\begin{array}{c}\text { Presentase } \\
\text { Keberhasilan \% }\end{array}$ \\
\hline 1 & Baik & 93,33 \\
2 & Cukup & 6,67 \\
3 & Kurang & 0,00 \\
\hline & Jumlah & $\mathbf{1 0 0}$ \\
\hline
\end{tabular}

Sumber: Hasil analisis 2018
Berdasarkan tabel 9 diatas maka dapat diketahui bahwa dari keseluruhan kegiatan menunjukkan bahwa presentase kegiatan siswa pada siklus II menunjukkan 93.33 persen siswa berkelakuan baik, 6,67 persen siswa berkelakuan cukup, dan tidak ada siswa yang berkelakuan kurang. Dari tabel diatas dapat di simpulkan bahwa siswa yang mengikuti kegiatan belajar pada siklus II mengalami peningkatan dibandingkan sikuls I yaitu dari 80,30 siswa yang berkelakuan baik meningkat menjadi 93,33 siswa pada siklus II.

\section{2) Hasil Analisis Kuantiatif}

\section{d. Deskripsi Hasil Belajar Akhir Siklus II}

Pada akhir Siklus II ini juga diadakan tes hasil belajar yang berbentuk ulangan harian setelah penyajian satu pokok bahasan. Adapun deskriptif skor hasil belajar Bahasa Indonesia siswa setelah diberi tindakan pada Siklus II dapat dilihat pada tabel berikut :

Tabel 10 Statistik Skor Hasil Belajar Bahasa Indonesia Pada Siklus II

\begin{tabular}{cc}
\hline Statistik & Nilai Statistik \\
\hline Subjek & 32 \\
Skor ideal & 100 \\
Skor tertinggi & 95 \\
Skor terendah & 60 \\
Rentang skor & 35 \\
Skor rata-rata & 79,12 \\
\hline
\end{tabular}

Sumber : Olah Data Hasil Belajar Siswa, 2018

Apabila skor hasil belajar di atas dikelompokkan ke dalam lima kategori maka diperoleh distribusi frekuensi seperti ditunjukkan pada tabel berikut :

Tabel 11 Distribusi Frekuensi Dan Persentase skor Hasil Belajar Bahasa Indonesia Pada Siklus II

\begin{tabular}{cccc}
\hline No & Skor & Kategori & Frekuensi \\
\hline 1. & $0-34$ & Sangat Rendah & 0 \\
2. & $35-54$ & Rendah & 0 \\
3. & $55-64$ & Sedang & 2 \\
4. & $65-84$ & Tinggi & 15 \\
5. & $85-100$ & Sangat Tinggi & 7 \\
\hline \multicolumn{4}{l}{ Sumber : Olah Data Hasil Belajar Siswa, 2018 }
\end{tabular}


Berdasarkan tabel 11 di atas, dapat disimpulkan bahwa dari 24 siswa sudah tidak terdapat lagi siswa yang berada pada kategori sangat rendah, dan tidak terdapat juga siswa yang tingkat hasil belajar Bahasa Indonesianya pada kategori rendah, pada kategori sedang sekitar 2 siswa, pada kategori tinggi 15 siswa, serta 7 siswa yang tingkat hasil belajar Bahasa Indonesianya berada pada kategori sangat tinggi.

Apabila hasil belajar siswa pada siklus II dianalisis sesuai standar ketuntasan yang di berikan oleh sekolah, maka persentase ketuntasan belajar siswa pada siklus II dapat dilihat pada tabel 12 berikut:

Tabel 12 Deskripsi Ketuntasan Belajar Siswa Kelas XII IPA 1 SMA Negeri 10 Bulukumba Siklus II

\begin{tabular}{|c|c|c|c|c|}
\hline No & $\begin{array}{c}\text { Interval } \\
\text { skor }\end{array}$ & Kategori & Frekuensi & $\begin{array}{c}\text { Persentase } \\
(\%)\end{array}$ \\
\hline 1 & $0-74$ & Tidak & 2 & 8,30 \\
\hline 2 & $\begin{array}{c}75- \\
100\end{array}$ & $\begin{array}{l}\text { tuntas } \\
\text { Tuntas }\end{array}$ & 22 & 91,70 \\
\hline \multicolumn{3}{|c|}{ Jumlah } & 24 & 100 \\
\hline
\end{tabular}

Sumber : Olah Data Hasil Belajar Siswa, 2018

Dari tabel 12 di atas menunjukkan bahwa pada siklus II persentase ketuntasan belajar sebesar 22 dari 24 siswa termasuk dalam kategori tuntas dan sebesar 2 orang dari 24 siswa termasuk dalam kategori tidak tuntas. Artinya dari tes siklus I hingga tes siklus II sudah mengalami peningkatan persentase ketuntasan klasikal, dan sudah berada di atas standar persentase ketuntasan klasikal. Hal ini disebabkan karena pada siklus II ini, para siswa sudah mulai serius dalam belajar dan memperhatikan tugas-tugas yang diberikan untuk diselesaikan dan setelah dilakukan pembenahan mengenai hal-hal yang dianggap kurang pada siklus I.

Siswa yang belum tuntas mulai dari sebelum pemberian tindakan sampai setelah pemberian tindakan yaitu pada siklus I sampai siklus II meskipun sudah diberikan program perbaikan namun hasilnya tidak jauh beda dari hasil sebelumnya dan ternyata setelah dinyatakan yang menjadi kendala sehingga mereka tidak dapat mencapai ketuntasan belajar seperti siswa yang lain, ini disebabkan karena mereka malas bertanya apabila ada hal yang kurang dimengerti, kurang memperhatikan pelajaran, apabila ada tugas tidak dikerjakan dengan baik, dan kurang kontrol dari orang tua pada saat mereka ada di rumah. Dari hasil belajar yang telah diperoleh siswa, setelah dilakukan proses Pembelajaran Kooperatif Tipe Question Student Have, meningkat dari siklus I ke Siklus II ini jelas terlihat pada beberapa tabel di atas.

\section{d. Refleksi}

Berdasarkan hasil observasi dan refleksi setelah pelaksanaan siklus II terlihat bahwa hasil belajar Bahasa Indonesia siswa terjadi peningkatan hasil belajar siswa dari kategori sedang pada Siklus I dan Siklus II pada kategori tinggi dengan skor rata-rata 66,70 menjadi 79,12 sehingga mengalami peningkatan sebesar 1,17 dari skor ideal.

\section{Pembahasan}

Penelitian ini dilakukan secara kolaborasi dengan pendidik mata pelajaran Bahasa Indonesia sebanyak dua siklus. Observasi dilakukan bersamaan dengan brlangsungnya tindakan, pada siklus I diperoleh data bahwa belum semua siswa berpartisipasi aktif dalam pembelajaran. Terlihat masih banyak siswa yang belum antusias mengikuti pembelajaran, dan keaktifan siswa dalam memberikan tanggapan atau berkomentar masih sangat rendah. Akan tetapi meskipun antara tes awal (sebelum penerapan model pembelajaran kooperatif tipe Question Student Have) dengan siklus I (setelah penerapan model pembelajaran kooperatif tipe Question Student Have) terjadi peningkatan akan tetapi belum menunjukkan ketercapaian indikator keberhasilan di dalam penelitian ini. Sehingga hal tersebut mengharuskan penelitian harus dilanjutkan ke siklus II dengan menggunkan model pembelajaran kooperatif tipe Question Student Have. 
Pada siklus II diadakan perbaikan tindakan dan terlihat siswa lebih antusias mengikuti pembelajaran. Siswa lebih aktif dalam kelompoknya, dan terlihat pula peningkatan siswa dalam memberikan tanggapan, dan lebih banyak lagi siswa yang antusias berkomentar mengenai materi pembelajaran yang dibahas. Pada siklus II juga terlihat situasi kelas yang sudah teratur, dan siswa juga lebih tertib dalammengikuti proses belajar mengajar. Pada siklus ini komunikasi yang baik antara pendidik dan siswa lebih baik, siswa sudah mulai fokus dengan pembelajaran yang sedang dijelaskan oleh pendidik. Dan pertanyaan yang diajukan siswa lebih beragam dibandingkan pertanyaan-pertanyaan yang diajukan pada siklus I yang cenderung monoton.

Hasil analisis terhadap hasil belajar siswa menunjukkan bahwa dari siklus I samapai siklus II mengalami peningkatan. Hasil belajar Bahasa Indonesia siswa Kelas XII IPA 1 SMA Negeri 10 Bulukumba dari kategori sedang pada Siklus I dan Siklus II pada kategori tinggi dengan skor rata-rata 66,70 menjadi 79,12 sehingga mengalami peningkatan sebesar 1,17 dari skor ideal. Secara umum hasil penelitian yang telah dicapai setelah pelaksanaan tindakan dengan pembelajaran Kooperatif Tipe Question Student Have mengalami peningkatan. Sehingga tentunya telah memberikan dampak positif terhadap peningkatan hasil belajar Bahasa Indonesia siswa.

Umumnya sebagian besar siswa menanggapi model pembelajaran kooperatif tipe Question Student Have dengan positif, mereka menganggap bahwa dengan pembelajaran kooperatif tipe Question Student Have mereka dapat bekerja sama dan bertukar pendapat dengan teman kelompoknya. Mereka juga memberikan tanggapan agar pendidik lebih tegas dalam mengawasi setiap kelompok, sehingga tidak ada siswa yang mengganggu siswa lainnya atau kelompok yang satu ribut sehingga mengganggu kelompok lainnya.

Fakultas Keguruan dan Ilmu Pendidikan Universitas Bosowa Makassar

\section{KESIMPULAN}

Berdasarkan analisis data dan pembahasan, maka dapat ditarik kesimpulan bahwa hasil belajar Bahasa Indonesia siswa Kelas XII IPA 1 SMA Negeri 10 Bulukumba mengalami peningkatan setelah diadakan pembelajaran kooperatif tipe Question Student Have, dengan indikasi sebagai berikut :

1. Hasil belajar Bahasa Indonesia siswa Kelas XII IPA 1 SMA Negeri 10 Bulukumba setelah diberi tindakan pada Siklus I berada pada kategori sedang dengan skor rata-rata 66,70 dari skor ideal 100.

2. Hasil belajar Bahasa Indonesia siswa Kelas XII IPA 1 SMA Negeri 10 Bulukumba setelah diberi tindakan pada Siklus II berada pada kategori tinggi dengan skor rata-rata 79,12 dari skor ideal 100.

3. Terjadi peningkatan hasil belajar siswa dari kategori sedang pada Siklus I dan Siklus II pada kategori tinggi dengan skor rata-rata 66,70 menjadi 79,12 sehingga mengalami peningkatan

4. Persentase kehadiran siswa juga mengalami peningkatan dari 97,5 persen menjadi 98,3 persen pada siklus II .

5. Pembelajaran kooperatif tipe Question Student Have dalam kegiatan belajar mengajar dapat memberikan motivasi kepada siswa agar lebih inovatif dan kreatif dalam membuat pertanyaan serta mengemukakan pertanyaan pertanyaan dan tidak canggung untuk mengemukakan pendapatnya.

\section{DAFTAR PUSTAKA}

Ariani. Ririn. (2013). Pengaruh Penggunaan Metode Pembelajaran Kooperatif Tipe Question Student Have Terhadap Hasil Belajar Siswa Kelas 
$\mathrm{X}$ SMA Negeri 10 Kota Jambi. Skripsi. Unpublished.

Departemen Pendidikan dan Kebudayaan. (1993). Evaluasi dan Penilaian. Jakarta : Proyek Peningkatan Mutu Guru. Dirjen Dikdasmen.

Dewi. Yuliana. (2013). Penerapan Metode Question Student Have Dalam Model Pembelajaran Kooperatif Untuk Peningkatan Pembelajaran IPS Siswa Kelas V SD Negeri 1 Banyumudal. Skripsi. Unpublished.

Haling, A. dkk. (2006). Belajar dan Pembelajaran. Makassar: Badan Penerbit UNM.

Huda, Miftahul. (2011). Cooperative Learning Metode, Teknik, Struktur dan Model Penerapan. Yogyakarta: Pustaka Pelajar

Jihad, Asep \& Haris, Abdul. (2013). Evaluasi Pembelajaran.Yogyakarta: Multi Prossindo

Kustawan. Dedy. (2013). Analisis Hasil Belajar. Bandung: Luxima.

Noviansa. Opi. (2013). Penerapan Model Pembelajaran Kooperatif Tipe Question Student Have Pada Konsep Ekosistem di Kelas VII SMP Negeri 5 Tasikmalaya. Skripsi. Unpublished.

Rusdi. (1998). Peningkatan Kemampuan Guru Dalam Mengorganisasi Cooperative Learning Pada Pengajaran Matematika SD. Jurnal Penelitian Pendidikan Dasar, No 4, 1 - 10. Jakarta : PPGSD.

Sadirman AM., (2012). Interaksi dan Motivasi Belajar Mengajar. Jakarta: PT Raja Grafindo Persada

Sagala, Syaiful. (2006). Konsep dan Makna Pembelajaran. Bandung: Alfabeta

Sahabuddin. (2007). Mengajar Dan Belajar. Makassar: Badan Penerbit Universitas Negeri Makassar

Sanjaya, Wina. (2009). Penelitian Tindakan

Kelas. Kencana: Jakarta.

Fakultas Keguruan dan Ilmu Pendidikan Universitas Bosowa Makassar
Slameto. (2003). Belajar dan Faktor-faktor yang Mempengaruhinya. Jakarta: Rineka Cipta

Slavin. Robert E. (2005). Cooperative Learning, Riset dan Praktik. Bandung: Nusa Media

Sudrajat. (2003). Implementasi Kurikulum Berbasis Kompetensi; Pembaharuan pendidikan dalam Undang-Undang Sisdiknas. Bandung: Cipta Cikas Grafika

Suprihatiningrum, Jamik. (2013). Strategi Pembelajaran. Yogyakarta: Ar- Ruzz Media.

Suprijono, Agus. (2009). Cooperative Learning Teori dan Aplikasi PAIKEM. Yogyakarta: Pustaka Pelajar

Suyono dan Hariyanto. (2012). Belajar dan Pembelajaran Teori dan Konsep Dasar. Bandung: PT. Remaja Rosda Karya Offset

Tim Pengembangan MKDP Kurikulum dan Pembelajaran, (2011). Kurikulum dan Pembelajaran. Jakarta: PT.Raja Grafindo Persada

Trianto. (2009). Mendesain Model Pembelajaran Inovatif-Progresif. Kencana: Jakarta. 